\title{
Molecular Diagnostics of Brain Tumours by Measuring the 5-Methylcytosine Level in Their DNA
}

\author{
Anna-Maria Barciszewska ${ }^{1}$, Stanisław Nowak ${ }^{1}$, \\ Iwona Gawrońska² and Mirosława Barciszewska ${ }^{2}$ \\ ${ }^{1}$ Department of Neurosurgery and Neurotraumatology \\ Karol Marcinkowski University, School of Medical Sciences, Poznan \\ 2Institute of Bioorganic Chemistry of the Polish Academy of Sciences, Poznan
}

Poland

\section{Introduction}

Brain tumours form a group of neoplasms with distinct histological characteristics and different malignancies [Maher 2001]. Various molecular alterations occurring in brain tumors may have diagnostic and predictive values as they are connected with histologically determined tumour types and malignancy grades [Martinez et al. 2009; Martinez and Esteller 2010; Sciume et al. 2010]. Methylation of DNA cytosine residue at the carbon 5 position $\left(\mathrm{m}^{5} \mathrm{C}\right)$ is a common epigenetic marker in many eukaryotes and is often found in the sequence context of CpG. It is assumed that ca 5\% of all cytosine residues, i.e. $1 \%$ of the nucleic bases, in mammalian genomes are methylated. Although DNA methylation has been viewed as a stable epigenetic mark, studies in the past decade have revealed that this modification is not as static [Wu and Zhang 2010]. In fact, loss of DNA methylation (DNA hypomethylation), has been observed in the specific context and can occur through active, passive or random modification mechanisms. Although the genome in each cell within the body is identical, cell- and tissue-specific profiles of gene transcription, posttranscriptional modification, modifications and translation are specifically regulated by epigenetic mechanisms that include DNA methylation, histone modification and noncoding RNAs [Robertson 2005]. In the central nervous system epigenetic mechanisms serve as main regulators of homeostasis and plasticity development, which are sensitive to local and global environmental, vascular and systemic factors [Martinez and Esteller 2010].

It is generally accepted that cancer initiation and progression are linked to the disruption of red-ox balance of the cell [Grek and Tew 2010]. Current evidences support an idea that cancer cells are generated by enhanced reactive oxygen species (ROS) generation, their accumulation, and down regulation of antioxidant enzymes [Essick and Sam 2010]. The oxidative damage to the cell caused by ROS plays a critical role in the etiology and progression of different neoplasms in humans [Johnstone and Baylin 2010; Jomova and Valko 2011].

Oxygen radicals cause damage to DNA and chromosomes, induce epigenetic alterations, interact with oncogenes or tumour suppressor genes, and finally change the immunological mechanisms [Robertson 2005; Pelizzola and Ecker 2010]. 
5-methylcytosine $\left(\mathrm{m}^{5} \mathrm{C}\right)$, along with other DNA constituents and the cell components, are targets for ROS, of which the most reactive species is the hydroxyl radical $(\bullet \mathrm{OH})$. Hydroxyl radical causes a wide range of DNA lesions including base modifications, deletions and strands breakage. Radical oxidation of $\mathrm{m}^{5} \mathrm{C}$ leads to its modification including demethylation and deamination (Fig. 1). It results in decreasing the global (genomic) $\mathrm{m}^{5} \mathrm{C}$ content in cellular DNA (hypomethylation). Therefore DNA methylation ( $\mathrm{m}^{5} \mathrm{C}$ status) is a sensitive marker of the neoplasm formation effected by the oxidative damage reactions and very characteristic for cancer cells [Robertson 2005].

Measurements of $\mathrm{m}^{5} \mathrm{C}$ in DNA can be done either by analysing the pattern of methylated target sequences along individual DNA molecules or as an average methylation level at a single genomic locus across many DNA molecules [Rao and Balachandran 2002].

One should remember that $5 \%$ of $\mathrm{m}^{5} \mathrm{C}$ deaminates to thymine under moderately acidic conditions and $2-5 \%$ is converted to thymine during the standard overnight incubation with sodium bisulfite [Wu and Zhang 2010].

One can also measure the global DNA methylation changes [Li et al. 2009; Pelizzola and Ecker 2010]. To investigate whether hypomethylation has a causal role in tumour formation, we have analyzed the level of $\mathrm{m}^{5} \mathrm{C}$ in DNA of human brain tumour tissues using twodimensional thin layer chromatography (TLC) analysis of [32P] postlabelled DNA components. We have found a correlation of $\mathrm{m}^{5} \mathrm{C}$ global content in DNA of tumour tissues with their malignancy. We have shown that as $\mathrm{m}^{5} \mathrm{C}$ amount decreases, the tumour grade of malignancy increases. The elaborated method has a practical application potential in the clinical diagnostics and also as the DNA quality test.

\section{Materials and methods}

\section{Patients}

Patients with brain tumours have been operated at the Department of Neurosurgery and Neurotraumatology of Poznań University of Medical Sciences. Brain tumour samples from 577 patients were collected between 2007 and 2010 and stored at $-80^{\circ} \mathrm{C}$. Histopatological analysis was done in the Neuropathology Laboratory and tumours classified according to the 2007 WHO rules [Louis et al. 2007]. Informed consent for samples and data analysis was obtained from each patient.

\section{Isolation of DNA from brain tumor tissue}

DNA was isolated from tumour tissue according to the method described earlier [Miller et al. 1988] or with a commercial kit (A\&A Biotechnology, Poland).

\section{DNA hydrolysis, labeling and analysis}

Dried DNA $(1 \mu \mathrm{g})$ was digested with $0.02 \mathrm{U}$ of micrococcal nuclease $(\mathrm{MN})$ and $0.001 \mathrm{U}$ spleen phosphodiesterase II (SPD) to mononucleotides (Np) in $50 \mathrm{mM}$ succinate buffer $\mathrm{pH} 6$ containing $10 \mathrm{mM} \mathrm{CaCl}_{2}$ in $3.5 \mu \mathrm{l}$ total volume for $5 \mathrm{~h}$ at $37{ }^{\circ} \mathrm{C}$. Mononucleotides $(0.17 \mu \mathrm{g})$ were labelled with $0.1 \mu \mathrm{Ci}\left[\gamma^{-32} \mathrm{P}\right] \mathrm{ATP}\left(6000 \mathrm{Ci} \mathrm{mmol}^{-1}\right.$, USB $)$ and T4 polynucleotide kinase $(1.5 \mathrm{U})$ in $3 \mu \mathrm{l}$ of $10 \mathrm{mM}$ bicine- $\mathrm{NaOH} \mathrm{pH} 9.7$ buffer containing $10 \mathrm{mM} \mathrm{MgCl}, 10 \mathrm{mM}$ dithiothreitol and $1 \mathrm{mM}$ spermidine for $30 \mathrm{~min}$ at $37{ }^{\circ} \mathrm{C}$.

To remove inorganic phosphate (PPi) $3 \mu \mathrm{l}\left(10 \mathrm{U} \mathrm{ml}^{-1}\right)$ of apyrase (Sigma) in the same $10 \mathrm{mM}$ bicine- $\mathrm{NaOH}$ buffer $\mathrm{pH} 9.7$ was added and incubation was continued for $30 \mathrm{~min}$. Finally the $3^{\prime}$ phosphate was cleaved off with $0.2 \mu \mathrm{g}$ RNase P1 in $500 \mathrm{mM}$ ammonium acetate buffer $\mathrm{pH}$ 4.5 [Barciszewska 2007]. 
Separation of $\left[\gamma^{-32} \mathrm{P}\right] \mathrm{m}^{5} \mathrm{C}$ from other nucleotides was performed with thin layer chromatography (TLC) on cellulose plates (Merck) using isobutyric acid: $\mathrm{NH}_{4} \mathrm{OH}: \mathrm{H}_{2} \mathrm{O}$ $(66: 1: 17 \mathrm{vol} / \mathrm{vol})$ in the first dimension and $0.1 \mathrm{M}$ sodium phosphate $\mathrm{pH} 6.8$ - ammonium sulfate - n-propanol $(100 \mathrm{ml} / 60 \mathrm{~g} / 2 \mathrm{ml})$ in the second dimension. The chromatogram was analyzed with Phosphoimager using Image Quant Software. The amount of $\mathrm{m}^{5} \mathrm{C}$ was calculated as of the spot intensities ratio of $\left[\mathrm{m}^{5} \mathrm{C} /\left(\mathrm{m}^{5} \mathrm{C}+\mathrm{C}+\mathrm{T}\right)\right] \times 100$ and expressed as $\mathrm{R}$ coefficient. The analysis was repeated 3 times for each probe and results were evaluated.

\section{Results and discussion}

Low level of some reactive oxygen species (ROS) as superoxide, hydroxyl radical or hydrogen peroxide can enhance cellular survival and stimulate proliferation. However, when that is a concominant with chronic ROS production, redox homeostasis can become imbalanced and normal cells may undergo transformation [Rao and Balachandran 2002]. In the last years many data have been collected that link cell stress to various diseases including cancer, cardiovascular disease, diabetes and neurodegenerative disorders. Current evidence support the hypothesis that cancer cells are characterized by enhanced ROS generation, increased ROS accumulation and the degradation of antioxidant enzymes. There are many explanations how cellular stress induces a disease. It is known that the cell stress causes genetic and epigenetic changes and results in an altered cellular "memory" that drives diseases pathology [Robertson 2005]. The main risk for cancer is a chronic exposure and increasing DNA damage. There is a wealth of data which supports the idea that cancerous cells have aberrant patterns of epigenetic modifications. The best studied epigenetic modification is DNA methylation, which consists of the methyl group at carbon 5 of the cytosine. Methylation of cytosine residues in DNA provides a mechanism for a gene control expression.

DNA methylation in promotor region as well as coding sequences inhibits binding of regulatory protein and causes gene silencing [Frigola et al. 2005]. It has been estimated that up to $5 \%$ of cytosines are methylated in normal tissues and that this DNA methylation is necessary for controlling gene expression of tissue-specific housekeeping or imprinted genes and for maintaining genomic stability through silencing transposable elements of the genome. Genomic DNA can undergo changes not only in the sequence level but also by the addition or removal of chemical groups. Aberrant DNA methylation, appeared as either hyper-, or hypomethylation, is associated with changes in the phenotype of various diseases including brain tumours [Frigola et al. 2005].

The brain and other points of the nervous system are particularly vulnerable to the free radical damage for a number of reasons. The membrane lipids in brain contain high level of polyunsaturated fatty acid side chains, which are prone to free radical damage. Brain also takes up large quantities of oxygen contributing to the formation of reactive oxygen species. At the same time brain contains low level of antioxidant enzymes such as catalase, superoxide dismutase and glutathione peroxidase. Presence of iron, copper and manganese in the brain contribute significantly to the production of a highly reactive and very short living ROS via Fenton reaction [Kehrer 2000; Essick and Sam 2010]. Free radicals, and $\bullet \mathrm{OH}$ in particular, cause damaging of DNA, proteins and lipids. They include for example 8hydroxy-2-deoxyguanosine, 4-hydroxy-2-nonenal and others [Fraga et al. 2002; Tudek et al. 2010]. 
Gliomas are the most common primary tumours affecting the human central nervous system (CNS). They are classified in accordance with their histopatological features and clinical presentation. The most abundance gliomas are astrocytomas, oligodendrogliomas and oligoastrocytomas [Louis et al. 2007]. Astrocytomas occur with an incidence of 80-85\% of all gliomas and glioblastoma multiforme (GBM) represent the most frequent malignant primary brain tumours. Various genes with frequent tumour related promoter hypermethylation have been identified in glioma [Martinez and Esteller 2010]. Gene regulation in tumours by promoter methylation has been established [Robertson 2005]. It has a prognostic and predictive potential in cancers. Therefore one can expect DNA methylation analysis to become an important diagnostic tool for many types of cancer.

Oxidative stress from aberrant accumulation of ROS over time can damage of proteins, lipids and nucleic acids and forms the molecular basis of free-radical background of cancer. It is well established that the oxidative stress is linked directly to cancer [Essick and Sam 2010; Grek and Tew 2010; Johnstone and Baylin 2010]. Although ROS modification to DNA has been broadly discussed in the past, its activity towards 5-methylcytosine, a main epigenetic marker, causing DNA demethylation has been overlooked for a long time [Berdasco and Esteller 2010].

Although DNA methylation has been recognized as a stable epigenetic mark, recently many data on loss of DNA methylation (DNA demethylation) has been collected. It can be that DNA demethylation is an active, enzymatic or chemical process of the methyl group removal through breaking a carbon-carbon bond. Genome-wide and gene-specific demethylation events are observed [Trewick et al. 2002; Martinez et al. 2009; Martinez and Esteller 2010]. The first occurs at specific times during early development, whereas the latter occurs in somatic cells responding to specific signals.

Many enzymes and various mechanisms have been proposed to carry out active DNA demethylation [ $\mathrm{Wu}$ and Zhang 2010]. They include base $\mathrm{m}^{5} \mathrm{C}$ excision repair, deamination of $\mathrm{m}^{5} \mathrm{C}$ to $\mathrm{T}$, nucleotide excision repair, oxidative demethylation and radical Sadenosylmethionine-based demethylation [Wu and Zhang 2010; Klug et al. 2010].

In addition to that, it is also possible for DNA to be demethylated randomly with very active hydroxyl radical [Kehrer 2000]. It is known that DNA molecule is subjected to a broad range of free radicals and oxidative injuries in vivo [Ulrey et al. 2005]. The oxidation reaction of with $-\mathrm{CH}_{3}$ group of $\mathrm{m}^{5} \mathrm{C}$ hydroxyl radical causes spontaneous demethylation or deamination leading to $\mathrm{C}$ or $\mathrm{T}$, respectively (Fig. 1).

The demethylation of $\mathrm{m}^{5} \mathrm{C}$ proceeds through 5-hydroxymethylcytosine intermediate [Guo et al. 2011]. The mechanism of this reaction is similar to that of radical SAM [Wu and Zhang 2010]. Imbalance of red-ox state in tumor cells affects the genomic methylation patterns what can be used to distinguish cancerous from normal brain cells, and to find correlations with their pathological features [Bart et al. 2005].

There are evidences which support the existence of DNA demethylation in vertebrate cells, although the mechanism of that process is not clear [Wu and Zhang 2010].

A low amount of $\mathrm{m}^{5} \mathrm{C}$ in human DNA and a limited availability of brain tumour tissues, prompted us to look for a new and suitable method of $\mathrm{m}^{5} \mathrm{C}$ determination with diagnostic

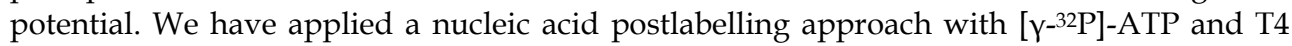
polynucleotide kinase (T4 PNK) to analyze DNA components with the thin layer two dimensional chromatography (TLC) and particularly for a quantitative assessment of the modified nucleotides (Fig. 2). 
<smiles>Cc1c[nH]c(=O)nc1N</smiles>

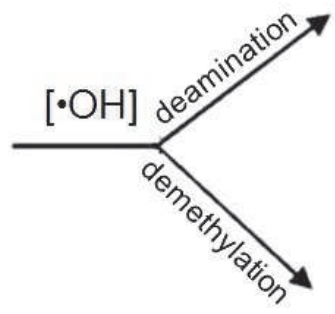<smiles>Cc1c[nH]c(=O)[nH]c1=O</smiles>

thymine<smiles>Nc1nc(=O)[nH]cc1CO</smiles><smiles>Nc1cc[nH]c(=O)n1</smiles>

5-hydroxymethylcytosine cytosine

Fig. 1. Formation of thymine and cytosine in the reaction of $\mathrm{m}^{5} \mathrm{C}$ in DNA with hydroxyl radical.

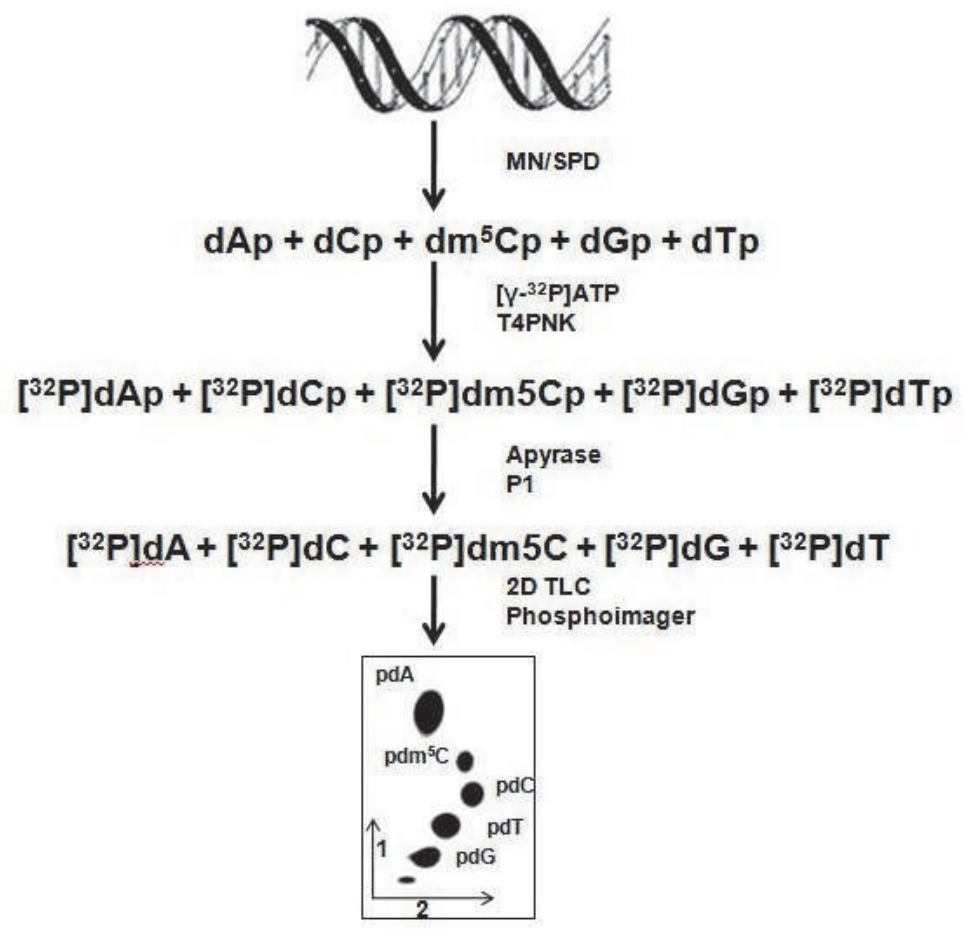

Fig. 2. Flow chart of $\mathrm{m}^{5} \mathrm{C}$ analysis in DNA hydrolyzed to $3^{\prime}$ mononucleotides $(\mathrm{Np})$. They are furthermore labelled with $\left[\gamma^{-32} \mathrm{P}\right]$ ATP, dephosphorylated of $3^{\prime}$ phosphate and separated with TLC in two dimensions (1 and 2). 
It seems that deamination and demethylation of $\mathrm{m}^{5} \mathrm{C}$ effected with hydroxyl radical oxidation, leads to thymine (T) and cytosine (C) formation, respectively (Fig. 1). These bases obtained from $\mathrm{m}^{5} \mathrm{C}$ are naturally occurring in DNA and therefore we included them in the equation: $\mathrm{R}=\left[\mathrm{m}^{5} \mathrm{C} /\left(\mathrm{m}^{5} \mathrm{C}+\mathrm{C}+\mathrm{T}\right)\right] \times 100$, for $\mathrm{m}^{5} \mathrm{C}$ assessment. In this way $\mathrm{R}$ represents the amount of $\mathrm{m}^{5} \mathrm{C}$ in relation to all pyrimidines (basic bases) present in DNA. We assume $\mathrm{R}$ as global methylation coefficient.

Before we began the analysis of $\mathrm{m}^{5} \mathrm{C}$ in human brain tumours DNA, we have checked the effect of tissue samples handling on the assignment of $\mathrm{m}^{5} \mathrm{C}$. Tumour tissues were resected and handled in three different conditions. For the same tissue sample, one part was freshly frozen (FF), immediately put on dry ice, the other was formalin-fixed, paraffin embedded (FFPE) and the third one was stored for $3 \mathrm{hrs}$ at room temperature on the bench. For DNA isolation, the tissue from FFPE was recovered as described previously [Sanchez-Navarro et al. 2010]. DNA isolated from all differently treated tissue samples showed changes in global amount of $\mathrm{m}^{5} \mathrm{C}$ (Fig. 3).

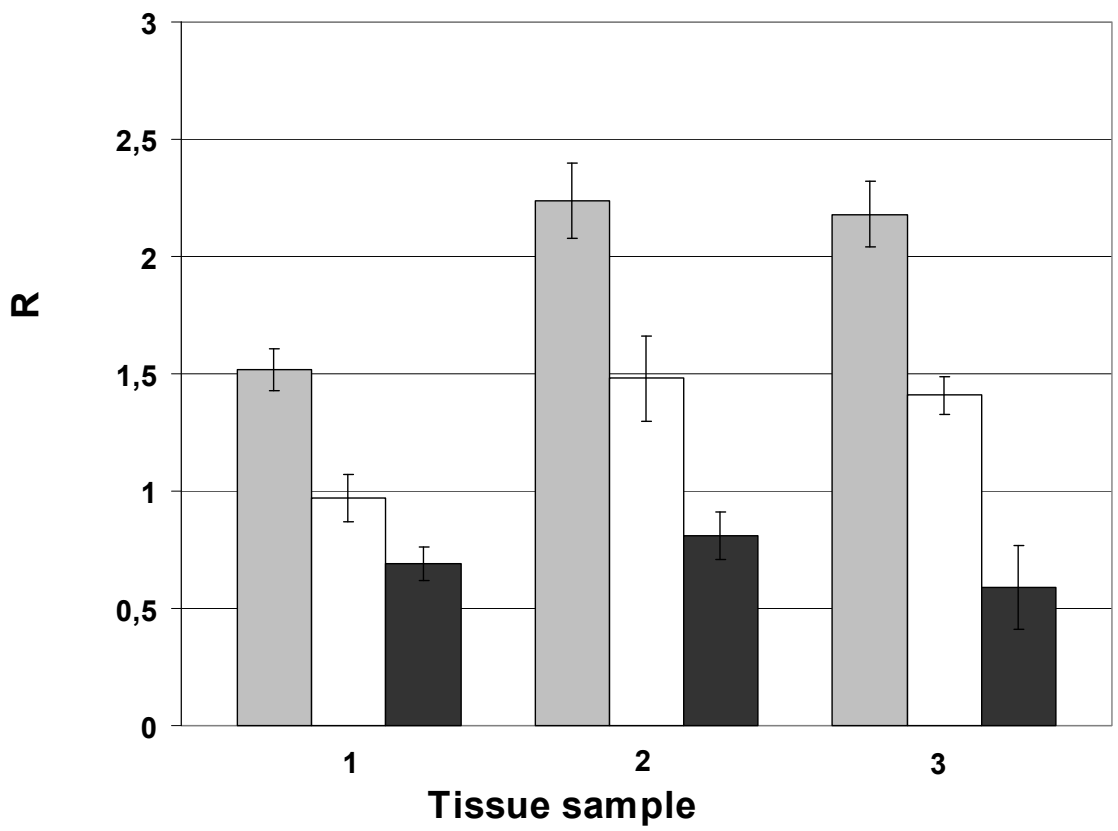

Fig. 3. The level of cytosine methylation $\left(\mathrm{m}^{5} \mathrm{C}\right)$ in DNA isolated from resected meningioma tissues and stored at $-80^{\circ} \mathrm{C}$ (grey), formaldehyde fixed, paraffin embedded (FFPE) (white) and exposed at room temperature for 3 hrs (black).

It is known that the development of molecular tests for clinical use has been limited by the lack of good available clinical samples for validation of candidate biomarkers. FF samples are difficult to collect and store for large scale studies, but FFPE samples on the other hand are stable at room temperature and easily to store. However the last approach has some disadvantages. Recently, it has been shown that RNA isolated from FFPE is a poor material for gene expression analysis due to its deep degradation [Farragher et al. 2006; SanchezNavarro et al. 2010]. 
Formalin fixation and paraffin embedding is the most commonly used method worldwide for tissue storage. This method preserves the tissue integrity but causes extensive damage to nucleic acids within the tissue. There is a huge resource of FFPE tissues specimens held in histopathology departments around the world. The samples provide an invaluable resource for studying the molecular basis of disease, making it possible to perform large retrospective studies correlation molecular features with therapeutic response and clinical out come [Farragher et al. 2008]. We have clearly showed that DNA in FFPE samples is degraded (Fig. 3) and observed significant demethylation in cellular DNA is due to oxidative damage [Tudek et al. 2010]. The highest DNA methylation level we observed for DNA isolated from fresh frozen tissues. The majority of studies to date have used high quality RNA from FF samples, however those studies have been restricted due to the small number of samples [Farragher et al. 2008]. Significantly lower amount of $\mathrm{m}^{5} \mathrm{C}$ was observed for FFPE tissues and severe hypomethylation for DNA from the cells stored at room temperature. One can conclude that $\mathrm{m}^{5} \mathrm{C}$ demethylation is effected by cellular oxidative damage which is reduced by deep freezing of a tissue sample immediately after tumor resection. A cellular damage occurring during embedding in paraffin, which includes heating up step in liquid paraffin, significantly stimulates demethylation has been observed earlier [Barciszewska et al. 2006; Blow 2007]. One can conclude that the decrease of DNA $\mathrm{m}^{5} \mathrm{C}$ is a consequence of severe DNA oxidation including $\mathrm{m}^{5} \mathrm{C}$ with $\bullet \mathrm{OH}$.

The goal of our studies was to understand the biology of malignant gliomas on the level that leads to the development of new diagnostic method.

We have analyzed the global level $\mathrm{m}^{5} \mathrm{C}$ in DNA samples from 577 individuals with brain tumours aged 11 - 80. Histopatological analysis of brain tumours was done according to WHO 2007 rules [Louis at al. 2007]. There were 285 males (49.5\%) and 292 (50.5\%) females.

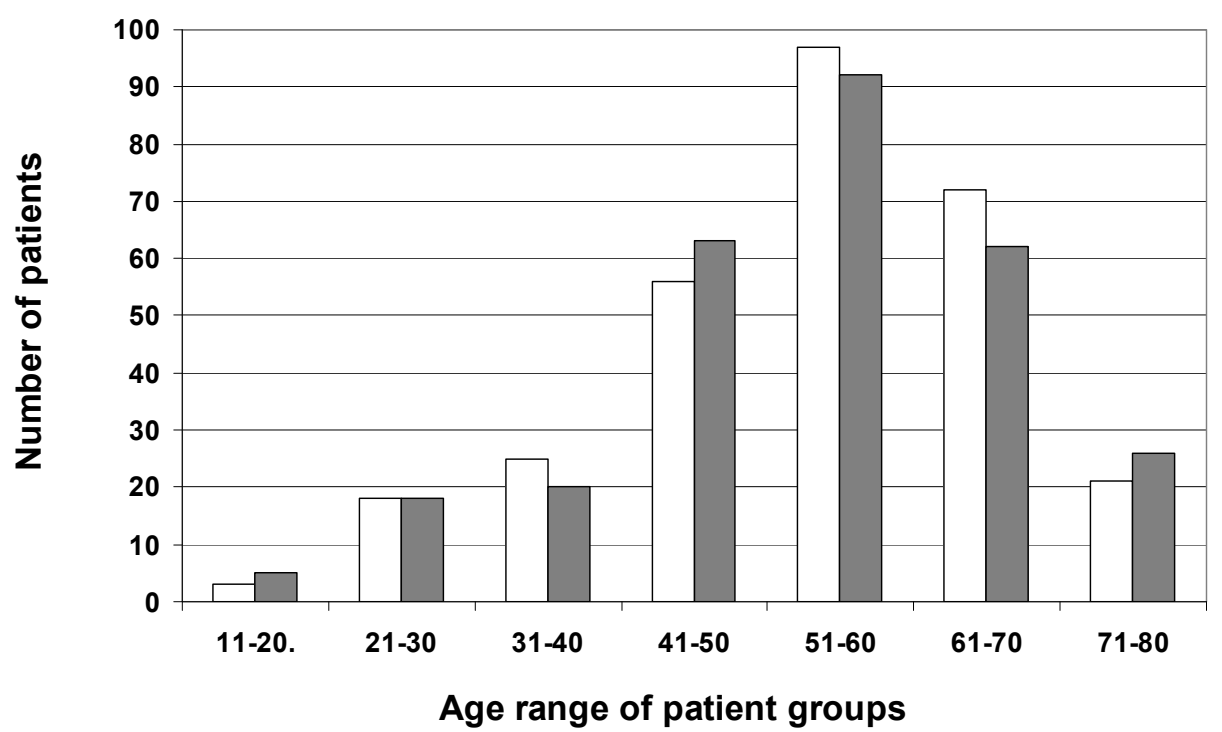

Fig. 4. Number of patients in the different age groups. Men - black bars, women - white bars. 
The biggest group included patients of 41-70 years old. The highest ratio of patients at the time of diagnosis showed a group aged 51-60 years. The median age of patients at the time of diagnosis was $53.4 \pm 13.2$ years (Fig. 4).

To correlate human brain tumours malignancy established with pathomorphological analysis with global DNA methylation, we have analyzed the genomic $\mathrm{m}^{5} \mathrm{C}$ content in DNA from human brain tissues of different gliomas. (Fig. 5, Table 1).

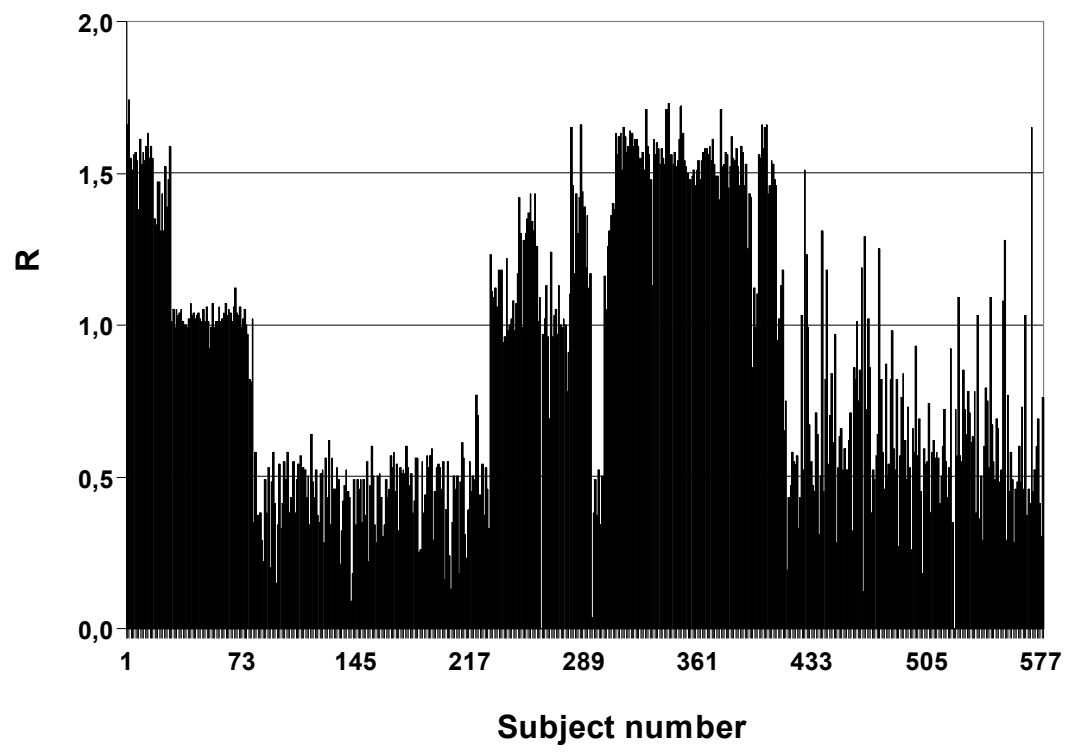

Fig. 5. 5-methylcytosine contents in DNA from patients with brain tumors.

Human tumours often display genome-wide DNA hypomethylation, which promotes cancer through the effect on chromosomal stability [Gaudet et al. 2003; Eden 2003; Yamada et al. 2005; Nishiyama et al. 2005].

One can see that $\mathrm{m}^{5} \mathrm{C}$ content in different human brain tumours varies very much (Fig. 5, Table 1). It is known that hydroxylation of $\mathrm{m}^{5} \mathrm{C}$ promotes active DNA demethylation in the adult brain [Guo et al. 2011]. Analysis patients' groups with high grade glioma shows that $\mathrm{m}^{5} \mathrm{C}$ content $(\mathrm{R})$ decrease as malignancy increases (Fig. 6). The most abundant are gliomas astrocytomas, oligodendrogliomas or tumours with morphological features of both astrocytes and oligodendrocytas called oligoastrocytomas (Table 1). The histological classification is followed by grading (from I to IV) which expresses the tumour malignancy with IV being the most malignant. Astrocytic tumours are subsequently graded with I (pilocytic astrocytoma), II e.g. diffuse astrocytoma, III (anaplastic astrocytoma) and IV (glioblastoma multiforme). Oligodendrogliomas and astrocytomas are graded furthermore as with grade II or III (anaplastic). The highest DNA demethylation is observed for glioblastoma multiforme (Fig. 6).

These results are in agreement with previous observations done for a smaller group of patients [Zukiel 2004]. Importantly these data are supported by others, showed that primary glioblastoma and established glioma cell lines show significant reduction of $\mathrm{m}^{5} \mathrm{C}$ content 
compared with normal brain tissue [Cadieux et al. 2006]. Furthermore one can see that grade III shows $\mathrm{R}$ in the range 1 - 1.2, but for WHO IV R coefficient is below 0.5 (Fig. 6). This is the lowest level of DNA methylation observed ever, not only for high grade gliomas. Because the correlation of $\mathrm{m}^{5} \mathrm{C}$ content (R) and WHO grade is linear (Fig. 6), therefore $\mathrm{R}$ can be used as a probe of tumorgenesis. One can clearly see that the global DNA methylation analysis easily differentiate low and high grade tumours as well as metastatic (Fig. 7). Different relations occur for meningeomas (Fig. 8, Table 2).

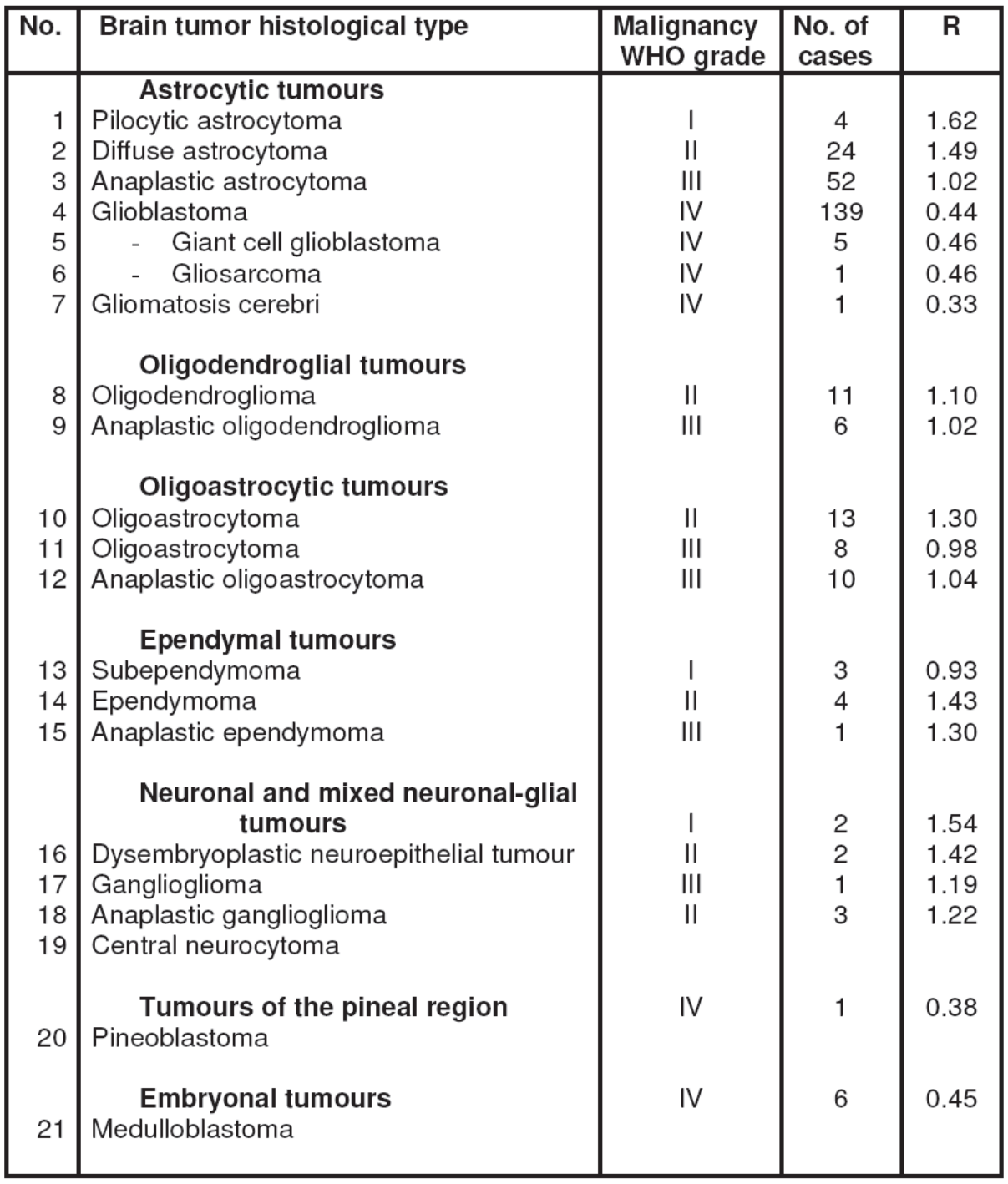

Table 1. The list of human brain tumours of neuroepithelial origin (total number 297) identified in patients. For each of them malignancy and $\mathrm{m}^{5} \mathrm{C}$ content $[\mathrm{R}]$ were established. 


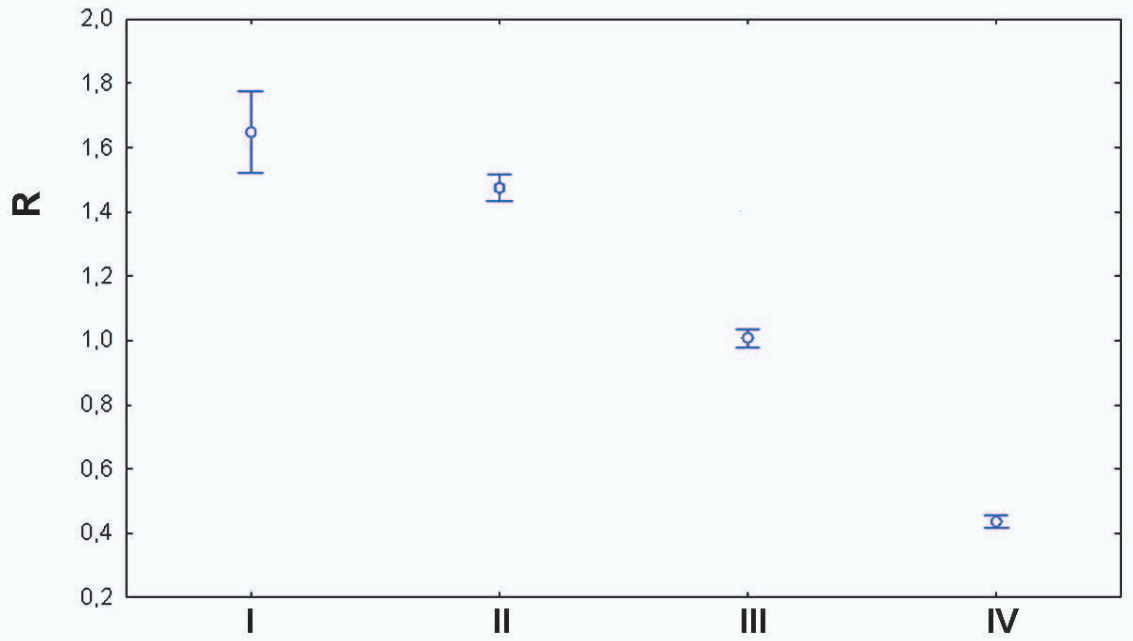

WHO grade

Fig. 6. The mean values $(\mathrm{p}<0.0002-0.0003)$ of global DNA $\left(\mathrm{m}^{5} \mathrm{C}\right)$ methylation expressed as $\mathrm{R}$ for different human gliomas with different malignancy grades (I-IV). See Table 1.

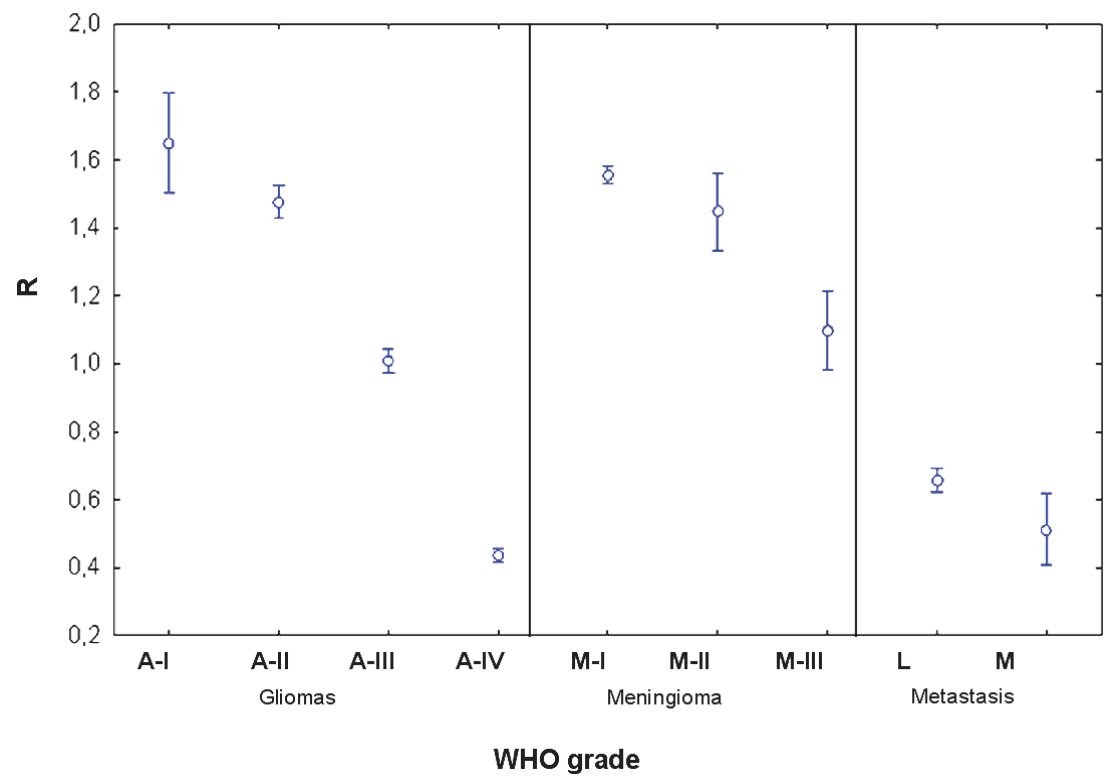

Fig. 7. The mean values $(\mathrm{p}<0,0002-0.0003)$ of $\mathrm{m}^{5} \mathrm{C}$ in DNA for gliomas (A-I - AIV), meningeomas (M-I - M-III) and metastasis (L-from lung, M-from melanoma skin cancer). 


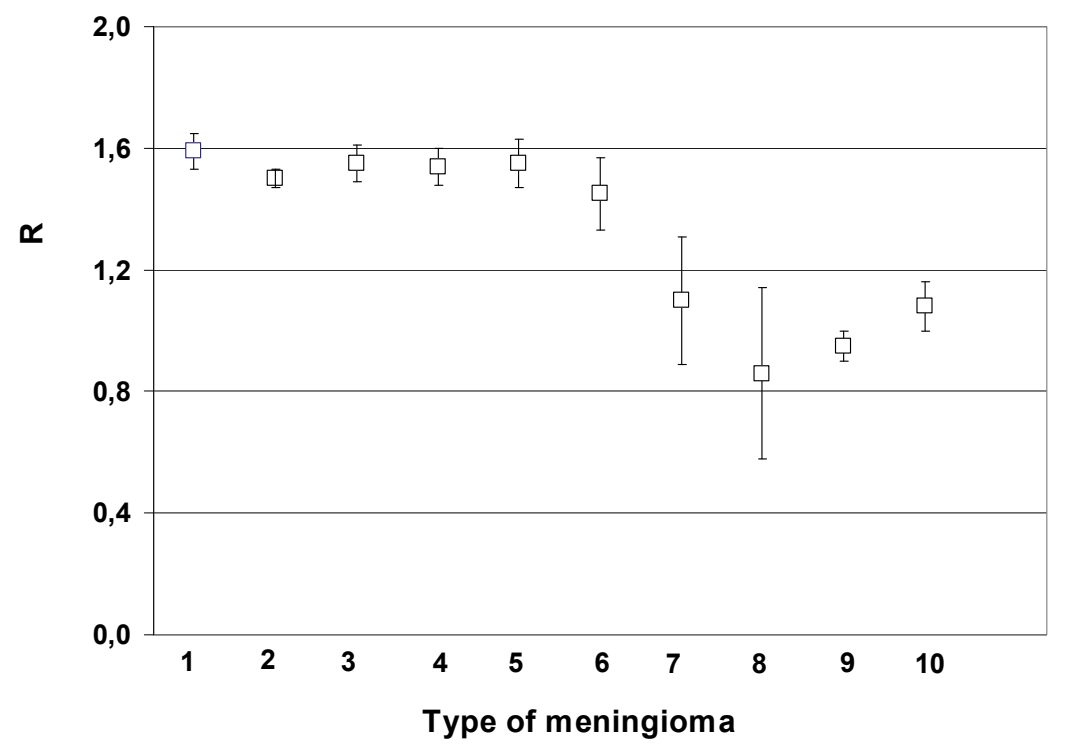

Fig. 8. The mean value of DNA methylation $\left(\mathrm{m}^{5} \mathrm{C}\right)$ for different meningiomas. 1 meningotheliale meningioma I; 2 - angiomatosum meningioma I; 3 - fibrosum meningioma I; 4 - psammomatous meningioma I; 5 - transitional meningioma II; 6 - atypical meningioma II; 7 -anaplastic meningioma III; 8 - haemangioblastoma I; 9 - haemangioma I; 10 - haemangiopericytoma III.

\begin{tabular}{|c|c|c|c|c|}
\hline No. & Brain tumor histological type & $\begin{array}{c}\text { Malignancy } \\
\text { WHO grade }\end{array}$ & $\begin{array}{l}\text { No. of } \\
\text { cases }\end{array}$ & $\mathbf{R}$ \\
\hline $\begin{array}{l}1 \\
2 \\
3 \\
4 \\
5 \\
6 \\
7\end{array}$ & $\begin{array}{l}\text { Tumours of meningothelial cells } \\
\text { Meningothelial meningioma } \\
\text { Fibrous meningioma } \\
\text { Transitional (mixed)meningioma } \\
\text { Psammomatous meningioma } \\
\text { Angiomatous meningioma } \\
\text { Atypical meningioma } \\
\text { Anaplastic (malignant) meningioma } \\
\text { Mesenchymal tumours } \\
\text { Haemangioma } \\
\text { Haemangiopericytoma } \\
\text { Other neoplasms related to the } \\
\text { meninges } \\
\text { Haemangioblastoma }\end{array}$ & $\begin{array}{c}\text { I } \\
\text { I } \\
\text { I } \\
\text { I } \\
\text { I } \\
\text { II } \\
\text { III }\end{array}$ & $\begin{array}{c}48 \\
22 \\
15 \\
4 \\
13 \\
5 \\
5\end{array}$ & $\begin{array}{l}1.59 \\
1.55 \\
1.55 \\
1.54 \\
1.50 \\
1.45 \\
1.10\end{array}$ \\
\hline
\end{tabular}

Table 2. The list of meningioma and their malignancies identified in patients as well as the amount of $\mathrm{m} 5 \mathrm{C}$ determined. 


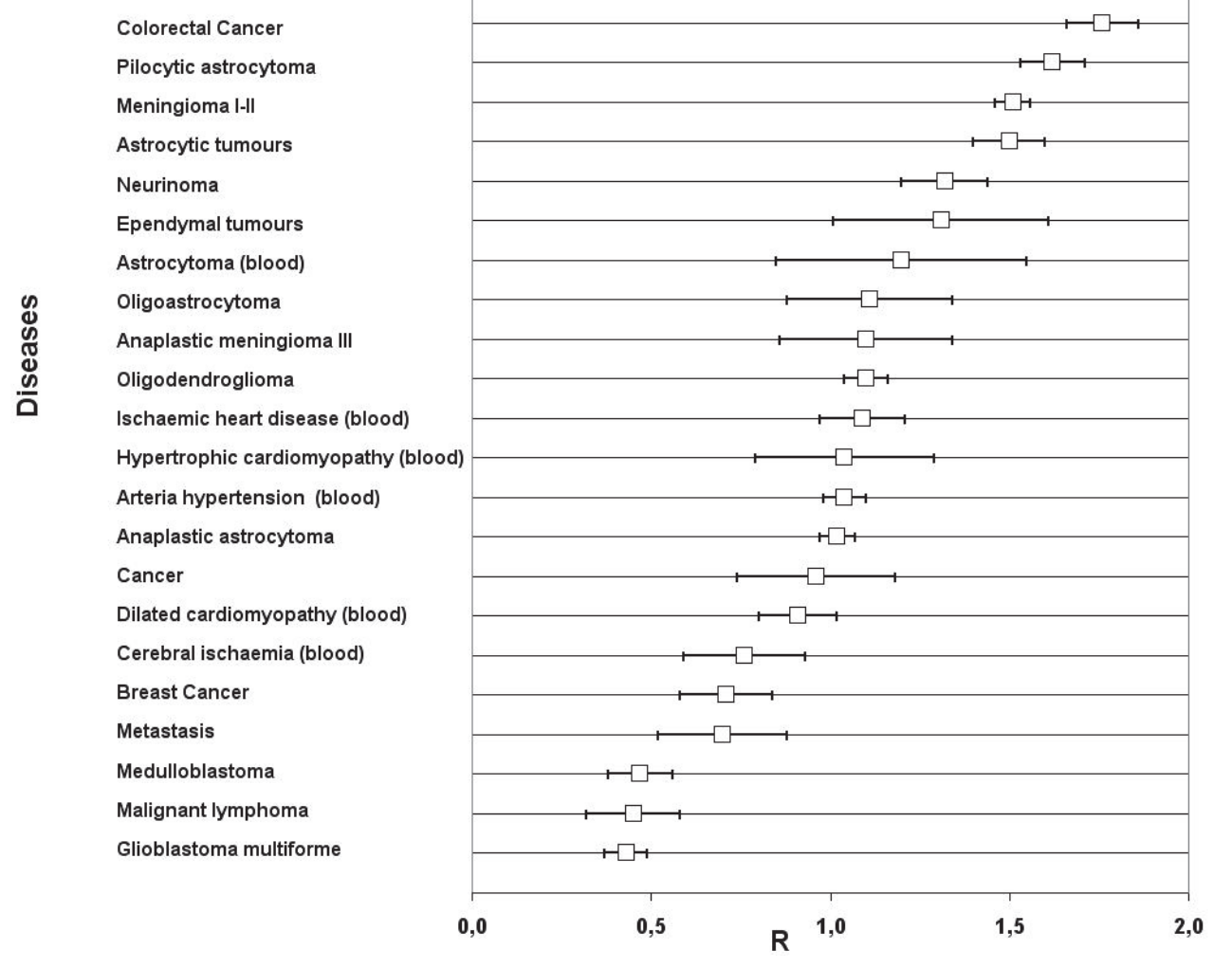

Fig. 9. R values for DNA isolated from tissues of different diseases. 
The DNA methylation in meningiomas is on very similar level. The R value is between 0.86 and 1.59. It means that red-ox processes in these tumour cells are not so intensive.

If so, one can ask whether genomic methylation level can be a good diagnostic marker for the early tumour detection in the clinical practice [Hatada et al. 2006]. We have found that the extent of DNA demethylation process is different and specific for various diseases (Fig. 9). The lowest level of DNA methylation is observed for very aggressive tumours like glioblastoma and anaplastic astrocytoma. On the other hand methylation of DNA in colorectal cancer or pilocytic astrocytoma is higher. One can also see different $\mathrm{m}^{5} \mathrm{C}$ content in DNA from blood of patients with other diseases. It means that the global methylation analysis can be used as diagnostic tool [Widschwendter and Jones 2002; Lavon et al. 2010] This method of nucleic acid compounds analysis can be also used as a quality control test of DNA. Currently for DNA isolation from different tissues, various isolation kits are used. Usually such material is good for cloning and enzymatic analysis However for molecular characteristic DNA should be RNA free. A contamination with RNA can be easily established with our method.

Mechanisms of regulation of DNA methylation are an important question, which has elicited much attention over the past decade. Recently many ideas have been proposed for mechanism of DNA demethylation. In addition to that, we have proposed a genomic one effected with hydroxyl radical oxidative damage. It turned out that the global methylation level of DNA provides information on grade cancer and progress of a disease.

\section{Acknowledgements}

This work was supported with the research grant from Ministry of Science and Informatization (MNII) Nr N N401 066338 (to M.B.) and N N403 219637 (to S.N.)

\section{References}

Barciszewska A-M, Murawa D, Gawronska I, Murawa P, Barciszewska MZ (2007) Analysis of 5-methylcytosine in DNA of breast and colon cancer tissues. IUBMB Life 59:1-6

Barciszewska A-M, Nowak S, Żukiel R i in (2006) Wpływ przechowywania tkanki nowotworowej na zawartość 5-metylocytozyny w DNA guzów mózgu. Neuroskop 8:160-162 (Poland)

Bart A, van Passel MW, van Amsterdam K, van der Ende A (2005) Direct detection of methylation in genomic DNA. Nucleic Acids Res 33:e124

Berdasco M, Esteller M (2010) Aberrant epigenetic landscape in cancer: how cellular identity goes awry. Dev Cell 19:698-711

Blow N (2007) Tissue issues. Nature 448: 959-962

Cadieux B, Ching TT, VadenBerg SR et al (2006) Genome-wide hypomethylation in human glioblastomas associated with specific copy number alteration, methylenetetrahydrofolate reductase allele status, and increased proliferation. Cancer Res 66:8469-8476

Eden A, Gaudet F, Waghmare A, Jaenisch R (2003) Chromosomal instability and tumors promoted by DNA hypomethylation. Science 300:455 
Essick EE, Sam F (2010) Oxidative stress and autophagy in cardiac disease, neurological disorders, aging and cancer. Oxid Med Cell Longev 3:168-177

Farragher SM, Tanney A, Kennedy RD, Harkin DP (2008) RNA expression analysis from formalin fixed paraffin embedded tissues. Histochem Cell Biol 130:435-445

Fraga MF, Uriol E, Borja Diego L, Berdasco M, Esteller M, Cañal MJ, Rodríguez R (2002) High-performance capillary electrophoretic method for the quantification of 5methyl 2'-deoxycytidine in genomic DNA: application to plant, animal and human cancer tissues. Electrophoresis 23:1677-1681

Frigola J, Sole X, Paz MF, Moreno V, Esteller M, Capella G, Peinado MA (2005) Differential DNA hypermethylation and hypomethylation signatures in colorectal cancer. Human Molecular Genetics 14:319-326

Gaudet F, Hodgson JG, Eden A, Jackson-Grusby L, Dausman J, Gray JW, Leonhardt H, Jaenisch R (2003) Induction of tumors in mice by genomic hypomethylation. Science 300:489-492

Grek CL, Tew KD (2010) Redox metabolism and malignancy. Curr Opin Pharmacol 10:362368

Guo JU, Su Y, Zhong Ch, Guo-li Ming G, Song H (2011) Hydroxylation of 5methylcytosine by TET1 promotes active DNA demethylation in the adult brain. Cell 145:1-12

Hatada I, Fukasawa M, Kimura M, Morita S, Yamada K, Yoshikawa T, Yamanaka S, Endo C, Sakurada A, Sato M, Kondo T, Horii A, Ushijima T, Sasaki H (2006) Genome-wide profiling of promoter methylation in human. Oncogene 25:3059-3064

Johnstone SE, Baylin SB (2010) Stress and the epigenetic landscape: a link to the pathobiology of human diseases? Nat Rev Genet 11:806-812

Jomova K, Valko M (2011) Advances in metal-induced oxidative stress and human disease. Toxicology 283:65-87

Kehrer JP (2000) The Haber-Weiss reaction and mechanisms of toxicity. Toxicology 149:4350

Klug M, Heinz S, Gebhard C, Schwarzfischer L, Krause SW, Andreesen R, Rehli M (2010) Active DNA demethylation in human postmitotic cells correlates with activating histone modifications, but not transcription levels. Genome Biol 11:R63

Lavon I, Refael M, Zelikovitch B, Shalom E, Siegal T (2010) Serum DNA can define tumorspecific genetic and epigenetic markers in gliomas of various grades. Neuro Oncol 12:173-180

Li M, Hu S, Shen Z, He X, Tao S, Dong L, Zhu Y (2009) High-performance capillary electrophoretic method for the quantification of global DNA methylation: Application to methotrexate-resistant cells. Anal Biochem 387:71-75

Louis DN, Ohgaki H, Wiestler OD, Cavenee WK, Burger PC, Jouvet A, Scheithauer BW, Kleihues P (2007) The 2007 WHO classification of tumours of the central nervous system. Acta Neuropathol 114:97-109

Maher EA, Furnari FB, Bachoo RM, Rowitch DH, Louis DN, Cavenee WK, DePinho RA (2001) Malignant glioma: genetics and biology of a grave matter. Genes Dev 15:1311-1333 
Martinez R, Esteller M (2010) The DNA methylome of glioblastoma multiforme. Neurobiol Dis 39:40-46

Martinez R, Martin-Subero JI, Rohde V, Kirsch M, Alaminos M, Fernandez AF, Ropero S, Schackert G, Esteller M (2009) A microarray-based DNA methylation study of glioblastoma multiforme. Epigenetics 4:255-264

Miller SA, Dykes DD, Polesky HF (1988) A simple salting out procedure for extracting DNA from human nucleated cells. Nucleic Acids Res. 16:1215

Nishiyama R, Qi L, Tsumagari K, Weissbecker K, Dubeau L, Champagne M, Sikka S, Nagai $\mathrm{H}$, Ehrlich M (2005) A DNA repeat, NBL2, is hypermethylated in some cancers but hypomethylated in others. Cancer Biol Ther 4:440-448

Pelizzola M, Ecker JR (2010) The DNA methylome. FEBS Lett. 2010 Nov 5. [Epub ahead of print

Rao AV, Balachandran B (2002) Role of oxidative stress and antioxidants in neurodegenerative diseases. Nutr Neurosci 5:291-309

Reale A, Matteis GD, Galleazzi G, Zampieri M, Caiafa P (2005) Modulation of DNMT1 activity by ADP-ribose polymers. Oncogene 24:13-19

Robertson KD (2005) DNA methylation and human disease. Nat Rev Genet 6:597-610

Sánchez-Navarro I, Gámez-Pozo A, González-Barón M, Pinto-Marín A, Hardisson D, López R, Madero R, Cejas P, Mendiola M, Espinosa E, Vara JA (2010) Comparison of gene expression profiling by reverse transcription quantitative PCR between fresh frozen and formalin-fixed, paraffin-embedded breast cancer tissues. Biotechniques 48:389397

Sciumè G, Santoni A, Bernardini G (2010) Chemokines and glioma: invasion and more. J Neuroimmunol 224:8-12

Soh Y, Shin MH, Lee JS, Jang JH, Kim OH, Kang H, Surh YJ (2003) Oxidative DNA damage and glioma cell death induced by tetrahydropapaveroline. Mutat Res 544:129-142

Trewick SC, Henshaw TF, Hausinger RP, Lindahl T, Sedgwick B (2002) Oxidative demethylation by Escherichia coli AlkB directly reverts DNA base damage. Nature 419:174-178

Tudek B, Winczura A, Janik J, Siomek A, Foksinski M, Oliński R (2010) Involvement of oxidatively damaged DNA and repair in cancer development and aging. Am J Transl Res 2:254-284

Ulrey CL, Liu L, Andrews LG, Tollefsbol TO (2005) The impact of metabolism on DNA methylation. Hum Mol Genet 14:R139-147

Widschwendter M, Jones PA (2002) DNA methylation and breast carcinogenesis. Oncogene 21:5462-5482

Widschwendter M, Jones PA (2002) The potential prognostic, predictive, and therapeutic values of DNA methylation in cancer. Clin Cancer Res 8:17-21

Wu SC, Zhang Y (2010) Active DNA demethylation: many roads lead to Rome. Nat Rev Mol Cell Biol 11:607-620

Yamada Y, Jackson-Grusby L, Linhart H, Meissner A, Eden A, Lin H, Jaenisch R (2005) Opposing effects of DNA hypomethylation on intestinal and liver carcinogenesis. Proc Natl Acad Sci USA 102:13580-13585 
Zukiel R, Nowak S, Barciszewska A-M, Gawrońska I, Keith G, Barciszewska MZ (2004) A simple epigenetic method for the diagnosis and classification of brain tumors. Mol Can Res 2:196-202 


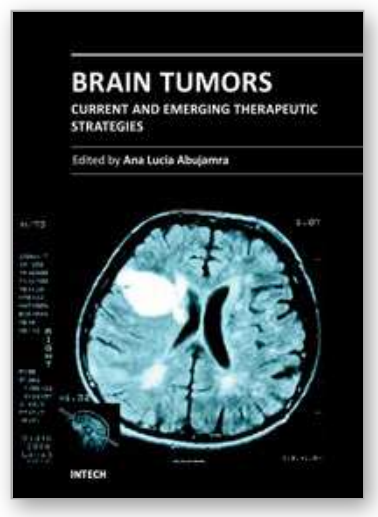

\author{
Brain Tumors - Current and Emerging Therapeutic Strategies \\ Edited by Dr. Ana Lucia Abujamra
}

ISBN 978-953-307-588-4

Hard cover, 422 pages

Publisher InTech

Published online 23, August, 2011

Published in print edition August, 2011

Brain Tumors: Current and Emerging Therapeutic Strategies focuses on tumor models, the molecular mechanisms involved in the pathogenesis of this disease, and on the new diagnostic and treatment strategies utilized to stage and treat this malignancy. A special section on immunotherapy and gene therapy provides the most up-to-date information on the pre-clinical and clinical advances of this therapeutic venue. Each chapter in Brain Tumors: Current and Emerging Therapeutic Strategies is authored by international experts with extensive experience in the areas covered.

\title{
How to reference
}

In order to correctly reference this scholarly work, feel free to copy and paste the following:

Anna-Maria Barciszewska, Stanisław Nowak, Iwona Gawrońska and Mirosława Barciszewska (2011). Molecular Diagnostics of Brain Tumours by Measuring the 5-Methylcytosine Level in Their DNA, Brain Tumors - Current and Emerging Therapeutic Strategies, Dr. Ana Lucia Abujamra (Ed.), ISBN: 978-953-307-588-4, InTech, Available from: http://www.intechopen.com/books/brain-tumors-current-and-emerging-therapeuticstrategies/molecular-diagnostics-of-brain-tumours-by-measuring-the-5-methylcytosine-level-in-their-dna

\section{INTECH}

open science | open minds

\section{InTech Europe}

University Campus STeP Ri

Slavka Krautzeka 83/A

51000 Rijeka, Croatia

Phone: +385 (51) 770447

Fax: +385 (51) 686166

www.intechopen.com

\section{InTech China}

Unit 405, Office Block, Hotel Equatorial Shanghai

No.65, Yan An Road (West), Shanghai, 200040, China

中国上海市延安西路65号上海国际贵都大饭店办公楼405单元

Phone: +86-21-62489820

Fax: +86-21-62489821 
(C) 2011 The Author(s). Licensee IntechOpen. This chapter is distributed under the terms of the Creative Commons Attribution-NonCommercialShareAlike-3.0 License, which permits use, distribution and reproduction for non-commercial purposes, provided the original is properly cited and derivative works building on this content are distributed under the same license. 